\title{
Hyaluronan production in human rheumatoid fibroblastic synovial lining cells is increased by interleukin $1 \beta$ but inhibited by transforming growth factor $\beta 1$
}

\author{
Makoto Kawakami, Kimihiro Suzuki, Yasunori Matsuki, Toshiaki Ishizuka, \\ Toshihiko Hidaka, Tatsuya Konishi, Mitsuyo Matsumoto, Koji Kataharada, \\ Haruo Nakamura
}

\begin{abstract}
Objectives-To investigate the regulatory roles of interleukin $1 \beta$ (IL1ß), tumour necrosis factor $\alpha(\mathbf{T N F} \alpha)$, interferon $\gamma$ $(\mathrm{IFN} \gamma)$ or transforming growth factor $\beta 1$ (TGFß1) on hyaluronan (HA) synthesis by human fibroblastic synovial lining cells. Methods-Concentrations of $\mathrm{HA}$ in culture supernatants of fibroblastic synovial lining cell line (RAMAK-1 cell line) with or without stimulation by IL1 $\beta$, TNF $\alpha$, IFN $\gamma$ or TGF $\beta 1$ were measured by sandwich binding protein assay. Levels of HA synthase mRNA of the cells with or without stimulation were detected by reverse transcribed polymerase chain reaction. Molecular weights of $\mathrm{HA}$ in the culture supernatants of the cells with or without stimulation were measured using high performance gel permeation liquid chromatography.

Results-HA synthesis by the cells was not significantly augmented by TNF $\alpha$ or by IFN $\gamma$. It was significantly stimulated by IL1 $\beta$ but inhibited by TGFß1. Molecular weights of $\mathrm{HA}$ in the culture supernatants of the cells were unchanged by stimulation with TNFo. They were remarkably increased by stimulation with IL1 $\beta$ and IFN $\gamma$, but reduced with TGF $\beta 1$.

Conclusion-IL1ß is an up regulator of HA synthesis, while TGF $\beta 1$ is a down regulator. HA production in the synovial lining cells of inflamed joints (for example, rheumatoid arthritis) might be regulated by the balance of these cytokines.

(Ann Rheum Dis 1998;57:602-605)
\end{abstract}

Hyaluronan (HA) is a linear glycosaminoglycan consisting of repeating units in which the sugars glucuronic acid and $\mathrm{N}$-acetyl glucosamine alternate. It exists as the tertiary structure of a random coil with a high molecular weight. Concentrations of HA are highest in musculoskeletal tissues, skin, embryological tissues, and synovial fluid. ${ }^{1} \mathrm{HA}$ plays an important part in wound healing, ${ }^{2}$ embryonic development, ${ }^{3}$ tumour growth, ${ }^{4}$ and synovial fluid viscosity. ${ }^{5}$

Cultured synovial fibroblasts produce HA. ${ }^{6}$ Immunohistochemical studies of normal synovium show that HA surrounds the lining layer cells but it is minimal in deeper layers. ${ }^{7}$ These results indicate that one of the fundamental functions of fibroblastic synovial lining cells is to produce HA and release it into synovial fluid, and to maintain constitutive HA concentrations in synovial fluid.

The mechanism regulating the production of HA in synovial lining cells has not yet been fully elucidated, perhaps because the preparation of a pure synovial lining cell population from whole synovial tissues requires tedious and demanding procedures. Recently, we derived a fibroblastic synovial lining cell line (RAMAK-1 cell line) from a patient with RA. ${ }^{8}$ The cells form a cystic tumour containing lubricating fluid enclosed by a lining layer when injected subcutaneously into severe combined immunodeficient mice, which suggests that these cells produce HA in this synovial fluid-like liquid.

The purposes of this study are to determine the regulatory roles of interleukin $1 \beta$ (IL1 $\beta$ ), tumour necrosis factor $\alpha(\mathrm{TNF} \alpha)$, interferon $\gamma$ $(\mathrm{IFN} \gamma)$ or transforming growth factor $\beta 1$ (TGF $\beta 1$ ) on HA production by the fibroblastic synovial lining cells.

\section{Methods}

CELL CULTURE

The fibroblastic lining cell line (RAMAK-1 cell line) was established as previously described. ${ }^{8}$ Cells were passaged every week in the ratio of $1: 20$. We used the cells at passages $20-25$ in the subsequent studies.

MEASUREMENT OF HA CONCENTRATION IN THE CULTURE SUPERNATANTS

RAMAK-1 cells in subconfluent populations $\left(5 \times 10^{4} \mathrm{cell} / \mathrm{cm}^{2}\right)$ on culture dishes (Cluster 3512, Costar, Cambridge, MA) were washed with RPMI-1640 medium (Nipro, Tokyo) and further cultured with RPMI-1640 medium containing $10 \%$ fetal bovine serum (FBS; Intergen, Purchase, NY) for either $24,48,78$ or 96 hours with or without stimulation by IL1 $\beta$ (1 ng/ml; Otsuka, Tokushima, Japan), TNF $\alpha$ (300 units/ml; Teijin, Tokyo), IFN $\gamma$ (1000 units/ml; Boehringer Mannheim Biochemica, Mannheim, Germany) or TGF $\beta 1$ (1 ng/ml; King Brewing, Kakogawa, Japan). Concentrations of HA in the supernatants of the cell culture were measured by a sandwich binding protein assay kit (Hyaluronan Plate Chugai, Chugai Pharmaceutica, Tokyo). Samples were incubated with HA binding protein coated on 


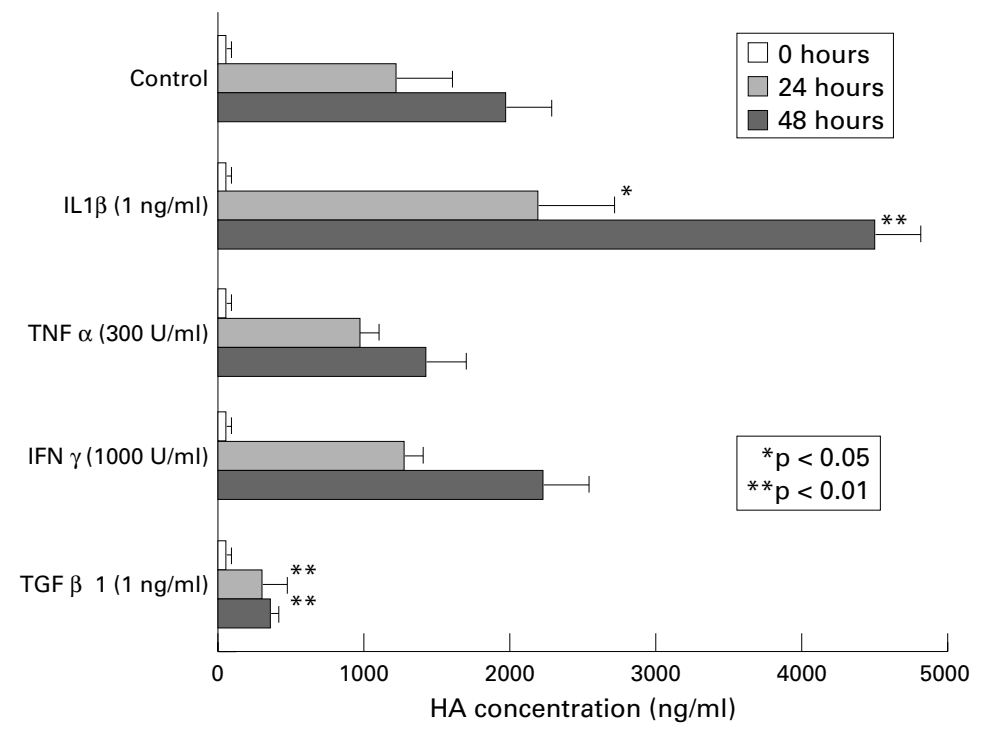

Figure 1 HA production by RAMAK-1 cells. RAMAK-1 cells were incubated for 24 or 48 hours in culture dishes with RPMI-1640 medium containing $10 \%$ FBS with or without stimulation by IL1 $\beta$ ( $1 \mathrm{ng} / \mathrm{ml}), T N F a$ (300 units $/ \mathrm{ml}), I F N \gamma$ (1000 units/ml) or TGF 1 $(1 \mathrm{ng} / \mathrm{ml})$. At the end of culture, the concentration of $\mathrm{HA}$ in the supernatants was measured by sandwich binding protein assay.

microplates for one hour at room temperature. After incubation, the microplates were washed three times with wash buffer, and further incubated with $100 \mu \mathrm{l}$ of peroxidase labelled liquid phase HA binding protein for 30 minutes at room temperature. After incubation, the microplates were washed three times with wash buffer, and further incubated with $100 \mu \mathrm{l}$ of peroxidase reactant substrate for 30 minutes at room temperature in a darkroom. The reaction was stopped by the addition of $0.18 \mathrm{M}$ sulphuric acid. The development of the colour was monitored at $450 \mathrm{~nm}$ with an Easy Reader ELISA analyser (SLT-Lab Instruments, Vienna, Austria). The HA level in each sample was calculated using the standard curve obtained with the purified HA solutions, which were included in the kit as references. According to the manufacturer's instructions, detection range of $\mathrm{HA}$ by the kit was $10-800 \mathrm{ng} / \mathrm{ml}$. If a sample contained more than upper limit of the measurable range, it was diluted with reaction buffer of the kit and measured again.

EXPRESSION OF HA SYNTHASE MRNA

Total cellular RNA from $1 \times 10^{6}$ cells with or without stimulation for six hours by IL1 $\beta$ (1 $\mathrm{ng} / \mathrm{ml}), \mathrm{TNF} \alpha$ (300 units $/ \mathrm{ml}), \operatorname{IFN} \gamma(1,000$ units/ml) or TGF $\beta 1$ (1 ng/ml), respectively, was isolated by a modified acid guanidinium thiocyanate/phenol/chloroform extraction method, using RNAzol B (Cinna/Biotecx Laboratories, Houston, TX). The RNA was reverse transcribed and the cDNA amplified by a polymerase chain reaction (RT-PCR), using a GeneAmp RNA PCR kit (Perkin-Elmer Cetus, Norwalk, CT). The primers of HA synthase (HA synthase 1), 5'-TGG GGC GGC AAG CGC GAG GTC ATG TAC ACA GC-3' (sense) and 5'-CAC CAG AGC GCG TTG TAC AGC CAC TCA CGG AAG TA-3' (antisense) were used. ${ }^{10-12}$ The primers of glyceraldehyde-3-phosphate dehydrogenase (GAPDH), 5'-GTC TTC ACC ACC ATG
GAG AAG GCT-3' (sense) and 5'-CAT GCC AGT GAG CTT CCC GTT CA-3' (antisense), were used for detecting the positive control cDNA. Each reaction contained $2 \mu \mathrm{l}$ of cDNA, $8 \mu \mathrm{l}$ of dNTP mixture, $10 \mu \mathrm{l}$ of $10 \times$ Taq DNA polymerase buffer, $8 \mu \mathrm{l}$ of $25 \mathrm{mM}$ $\mathrm{MgCl} 2,0.5 \mu \mathrm{l}$ AmpliTaq DNA polymerase (Perkin-Elmer Cetus), $1 \mu \mathrm{l}$ of each primer, and water to $100 \mu$. The samples were overlaid with mineral oil (Sigma, St Louis, MO) and cycled through 30 cycles of denaturation $\left(95^{\circ} \mathrm{C}\right.$ for one minute), annealing $\left(50^{\circ} \mathrm{C}\right.$ for two minutes), and extension $\left(72^{\circ} \mathrm{C}\right.$ for three minutes) in a programmable thermal controller (MiniCycler, MJ Research, MA). The PCR products were subjected to electrophoresis on $2 \%$ agarose gels (Agarose MP, Boehringer Mannheim Biochemica, Mannheim, Germany) and stained with ethidium bromide. The primer set of HA synthase amplifies a 548-bp sequence from cDNA transcribed from HA synthase mRNA.

MEASUREMENT OF HA MOLECULAR WEIGHT

The culture supernatants of the cells cultured for 96 hours with or without stimulation by IL $1 \beta, T N F \alpha$, IFN $\gamma$ or TGF $\beta 1$ were collected. The molecular weight of HA in each supernatant was measured at Seikagaku Kogyo Co (Tokyo) using high performance gel- permeation liquid chromatography (HPLC-GPC). Briefly, supernatants were separated on a TSKgel G6000PWXL column equipped with an HLC-8020 system (Toso, Tokyo), with 0.2 $\mathrm{M} \mathrm{NaCl}$ as the elution buffer. The molecular weight of HA in the samples was determined by the duration times through the column, reflected by those of HA standards. For calibration, purified HA standards (molecular weight $2130 \mathrm{kDa}, 460 \mathrm{kDa}$ or $104 \mathrm{kDa}$ ) were used.

STATISTICAL ANALYSIS

Data are expressed as mean (SD) values. Differences were analysed by the least significant difference test using a statistical program, StatMate II (Nankodo, Tokyo). Differences were regarded as statistically significant if $\mathrm{p} \leqslant 0.05$.

\section{Results}

HA PRODUCTION BY RAMAK-1 CELLS

HA concentrations in the supernatants of RAMAK-1 cells without stimulation were 1210 (385) ng/ml (24 hours) and 1964 (317) $\mathrm{ng} / \mathrm{ml}$ (48 hours) (fig 1). Although HA synthesis was not significantly augmented by TNF $\alpha$ (966 (152) ng/ml, 24 hours; 1418 (288) ng/ml, 48 hours) or by IFN $\gamma$ (1260 (136) ng/ml, 24 hours; 2214 (322) ng/ml, 48 hours) it was significantly stimulated by IL1 $\beta$ (2183 (541) $\mathrm{ng} / \mathrm{ml}, 24$ hours, $\mathrm{p}<0.05 ; 4488$ (328) ng/ml, 48 hours, $p<0.01$ ) (fig 1 ). In contrast, TGF $\beta 1$ significantly $(\mathrm{p}<0.01)$ inhibited HA production (300 (171) ng/ml, 24 hours; 357 (54) ng/ml, 48 hours) (fig 1).

The time and dose dependent inhibition of HA production by TGF $\beta 1$ was studied in another series of experiments. TGF $\beta 1$ (at concentrations of $0.1,1,5$ or $10 \mathrm{ng} / \mathrm{ml}$ ) 


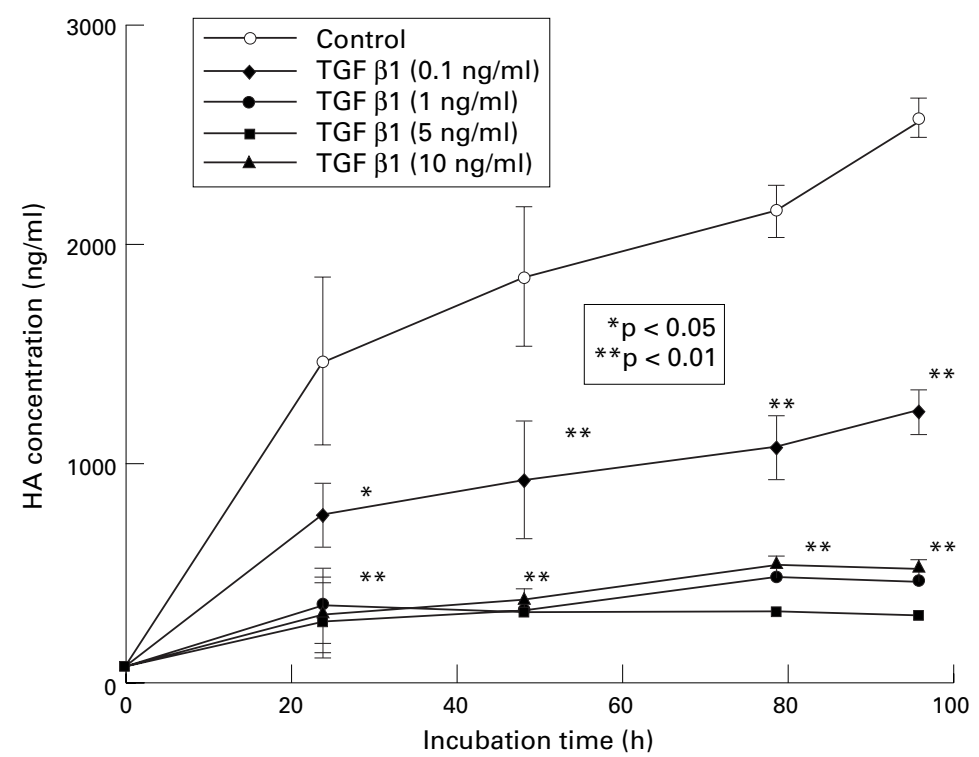

Figure 2 Time and dose dependent inhibition of HA production by RAMAK-1 cells cultured with RPMI-1640 medium containing $10 \%$ FBS with or without stimulation by TGF 1. Cells were incubated for up to 96 hours in the presence of TGF 1 . Supernatants were removed for $H A$ determinations by sandwich binding protein assay at 24, 48, 78 or 96 hours. TGFB1 concentrations indicated were used.

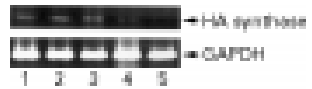

Table 1 Molecular weight of $H A$ secreted by RAMAK-1 cells with or without stimulation by IL1 $\beta, T N F a, I F N \gamma$ or $T G F \beta 1$

Figure 3 HA synthase $m R N A$ of RAMAK-1 cells when stimulated for six hours by IL1 $\beta, T N F a$, $I F N \gamma$ or TGF 1 using RT-PCR. Lane 1, without stimulation; lane 2 , with stimulation by IL1 $\beta$; lane 3 , with stimulation by TNFa; lane 4, with stimulation by IFN $\gamma$; lane 5, with stimulation by TGF 1 1. The primer set amplifies a 548-bp sequence from cDNA transcribed from $H A$ synthase $m R N A$.

\begin{tabular}{ll}
\hline & $\begin{array}{l}\text { Mean }(S D) \text { molecular weight } \\
(k D a)\end{array}$ \\
\hline Control & $770(160)$ \\
IL1 $\beta(1 \mathrm{ng} / \mathrm{ml})$ & $1270(270)^{\star}$ \\
TNF $\alpha(300 \mathrm{units} / \mathrm{ml})$ & $470(90)$ \\
IFN $\gamma(1000 \mathrm{units} / \mathrm{ml})$ & $1220(280)^{\star}$ \\
TGF $\beta 1(1 \mathrm{ng} / \mathrm{ml})$ & $170(20)^{\star \star}$ \\
\hline
\end{tabular}

${ }^{\star} \mathrm{p}<0.05,{ }^{\star \star} \mathrm{p}<0.01, \mathrm{n}=3$.

significantly $(p<0.05)$ inhibited the production of HA in this cell line compared with that of cells without stimulation (fig 2 ).

EXPRESSION OF HA SYNTHASE MRNA

RAMAK-1 cells expressed HA synthase mRNA in the absence of stimulation or when stimulated by IL $1 \beta, \mathrm{TNF} \alpha$ or IFN $\gamma$. In contrast, HA synthase mRNA was not detected in TGF $\beta 1$ stimulated cells (fig 3).

MOLECULAR WEIGHT OF HA BY RAMAK-1 CELLS The molecular wieght of HA in the culture supernatants of RAMAK-1 cells in the absence of stimulation was $770(160) \mathrm{kDa}$, whereas it was significantly $(\mathrm{p}<0.05)$ increased to 1270 (270) $\mathrm{kDa}$ or to 1220 (280) kDa with stimulation by IL1 $\beta$ ( $1 \mathrm{ng} / \mathrm{ml})$ or IFN $\gamma \quad(1000$ units $/ \mathrm{ml}$ ), respectively. In contrast, it was significantly $(\mathrm{p}<0.01)$ reduced to $170(20) \mathrm{kDa}$ with stimulation by TGF $\beta 1(1 \mathrm{ng} / \mathrm{ml})$ (table 1$)$.

\section{Discussion}

HA, isolated initially from the vitreous body of the eye, is an ubiquitous component of the extracellular matrix. ${ }^{13}$ It has been used for the clinical benefit of patients undergoing ocular operation $\mathrm{s}^{14}$ or with arthritic joint diseases. ${ }^{15-18}$ In joints, $\mathrm{HA}$ at the synovial lining layer or in synovial fluid retains water though the synovial vessels by its high water binding capacity and plays rheological or viscoelastic parts. ${ }^{15}{ }^{19} \mathrm{HA}$ concentrations are lower in rheumatoid synovium than in non-inflamed synovium. ${ }^{20} \mathrm{HA}$ synthesis by RAMAK-1 cell line is up regulated when stimulated by IL1 $\beta$ but is inhibited by TGF $\beta 1$ stimulation (figs 1,2 ). Inhibition of HA production by TGF $\beta 1$ was also confirmed by the disappearance of its synthase mRNAthat is, HA production was inhibited by TGF $\beta 1$ at the transcriptional level (fig 3).

With respect to the concentrations of TGF $\beta 1$, TGF $\beta 1$ at concentrations of $1 \mathrm{ng} / \mathrm{ml}$ and higher, served to increase prolyl 4-hydroxylase production by dermal fibroblasts. ${ }^{21}$ For the stimulation of rheumatoid synovial cells, $1-5 \mathrm{ng} / \mathrm{ml}$ of TGF $\beta 1$ were often used as optimal dose. ${ }^{22}{ }^{23}$ In this study, this cytokine at concentrations of $1-10 \mathrm{ng} / \mathrm{ml}$ remarkably inhibited HA production by RAMAK-1 cells.

Haubeck et $a l^{22}$ reported that IL1 $\beta$ and TGF $\beta 1$ were major stimulators of HA synthesis by synovial lining cells while $\mathrm{TNF} \alpha$ and IFN $\gamma$ were not. The findings in this study with respect to TGF $\beta 1$ are in direct contrast to those of Haubeck et al. ${ }^{22} \mathrm{~A}$ difference in the degree of cell differentiation or that in the behaviour of "normal" and "rheumatoid" synovial cells might be behind the contrasting observations. Haubeck et $a l^{22}$ used cells derived from normal synovial tissue, while we only used a cell line derived from synovial tissue of a patient with rheumatoid arthritis. Furthermore, they used Opti-MEM1 medium without the addition of serum to culture their synovial lining cells. Opti-MEM1 was developed to reduce the amount of added serum by more than $50 \%$, but it still requires a serum supplement. Finally, in their paper it is not clear whether or not cell viability was sustained for 60 hours without the addition of serum. In our culture system, a $10 \%$ addition of FBS maintained good viability of the cells. In fibroblast cultures, the addition of $10 \%$ FBS in culture medium augments basal HA synthesis. ${ }^{24}$ Differences in culture conditions might also have caused the discrepancy between our data with respect to TGF $\beta 1$ and those of Haubeck et al. ${ }^{22}$

With respect to culture condition, we used a $10 \%$ addition of FBS throughout the study. Other culture conditions, such as no serum or reduced serum concentrations, were not examined. If cells were cultured under such conditions, basal production of HA might have decreased, so that the inhibitory effect of TGF $\beta 1$ might have been less observed.

TGF $\beta 1$ is a potent inducer/modulator of a wide range of biological processes in many different systems, such as inhibition of growth, differentiation of several kinds of cells, ${ }^{25}{ }^{26}$ and suppression of inflammation. ${ }^{27}$ This cytokine is also referred to as a bifunctional regulator of cell function to emphasise its qualitatively heterogeneous effects. Intra-articular injection of TGF $\beta 1$ into normal rabbit joints induces synovial inflammation and hyperplasia with a predominantly mononuclear phagocyte infiltrate that contributes locally to joint inflammation. ${ }^{28}{ }^{29}$ In contrast, when administered systemically, 
TGF $\beta 1$ significantly ameliorates collagen type II induced arthritis or inhibits the development of streptococcal cell wall induced polyarthritis that is immunosuppressive and consistently shows therapeutically desirable effects. ${ }^{30} 31$ According to the results of this study, TGF $\beta 1$ might reduce the oedema of the soft connective tissues at the joints by inhibiting HA production. Inhibition of HA synthesis by TGF $\beta 1$ might improve the swelling of the inflamed joints, while the anti-inflammatory or analgesic effects ${ }^{32}$ of HA might lessen as HA production is reduced. The molecular weight of $\mathrm{HA}$ synthesised by RAMAK-1 cells with stimulation by IL $1 \beta$ or IFN $\gamma$ is strikingly augmented compared with that in the absence of stimulation (table 1). Interestingly, IFN $\gamma$ did not augment HA production in the light of total amount but significantly affected the molecular weight of HA. Although the precise mechanism for formation of high molecular weight of HA with stimulation by IL $1 \beta$ or IFN $\gamma$ was not elucidated, it is suggested that HA with a higher molecular weight produced by synovial lining cells in vivo could play a part as an anti-inflammatory and an analgesic effector ${ }^{32}$ by an interaction with HA receptor(s)..$^{33}$

Results of this study show that RAMAK-1 cells readily produce HA and that the production of HA is stimulated by IL1 $\beta$ and inhibited by TGF $\beta 1$. Therefore, overall HA production in the synovial lining cells of RA inflamed joints is likely to be regulated by a balance of these cytokines.

The authors thank Kaken Pharmaceutica and Seikagaku Kogyo Co for excellent technical assistance in measuring HA molecular weight.

1 Laurent TC, Fraser JR. Hyaluronan. FASEB J 1992;6:2397-40

2 Oksala O, Salo T, Tammi R, Hakkinen L, Jalkanen M, Inki $\mathrm{P}$, et al. Expression of proteoglycans and hyaluronan during wound healing. J Histochem Cytochem 1995;43:125-35.

3 Underhill CB, Nguyen HA, Shizari M, Culty M. CD44 positive macrophages take up hyaluronan during lung positive macrophages take up hyaluron.

4 Bartolazzi A, Peach R, Aruffo A, Stamenkovic I. Interaction between CD44 and hyaluronate is directly implicated in the regulation of tumor development. J Exp Med the regulation $1994 ; 180: 53-66$.

5 Swann DA, Radin EL, Nazimiec M, Weisser PA, Curran N, Swann DA, Radin EL, Nazimiec M, Weisser PA, Curran N,
Lewinnek G. Role of hyaluronic acid in joint lubrication. Lewinnek G. Role of hyaluronic acid
Ann Rheum Dis 1974;33:318-26.

Ann Rheum Dis 1974;33:318-26.
Vuorio E, Einola S, Hakkarainen S, Penttinen R. Synthesis of underpolymerized hyaluronic acid by fibroblasts cultured from rheumatoid and non-rheumatoid synovitis. Rheumatol Int 1982;2:97-102

7 Worrall JG, Bayliss MT, Edwards JC. Morphological localization of hyaluronan in normal and diseased synovium. Rheumatol 1991;18:1466-72.

8 Kawakami M, Kitani A, Matsukuma S, Hiroi S, Hara M, Ishizuka $\mathrm{T}$, et al. A novel synoviocyte line (RAMAK-1), derived from a patient with rheumatoid arthritis. In Vitro Cell Dev Biol 1998;34:85-87.

9 Kawakami M, Suzuki K, Matsuki Y, Hidaka T, Ishizuka T, Konishi $\mathrm{T}$, et al. Characterization of the newly established human type B synovial lining cell line, RAMAK-1; expression of adhesion molecules and cytokine production. Jpn J Rheumatol (in press)

10 Itano N, Kimata K. Molecular cloning of human hyaluronan synthase. Biochem Biophys Res Commun 1996;222: 816-20.
11 Shyjan AM, Heldin P, Butcher EC, Yoshino T, Briskin MJ. Functional cloning of the cDNA for a human hyaluronan ynthase. J Biol Chem 1996;271:2335-99.

12 Spicer AP, McDonald JA. Characterization and molecular evolution of a vertebrate hyaluronan synthase gene family. J Biol Chem 1998;273:1923-32.

13 Meyer KP, Palmer JW. The polysaccharide of the vitreous humor. J Biol Chem 1934;107:629-34.

14 Miller D, O'Connor P, Williams J. Use of Na-hyaluronate during intraocular lens implantation in rabbits. Ophthalmic Surg $1977 ; 8: 58$

15 Namiki O, Toyoshima H, Morisaki N. Therapeutic effect of intra-articular injection of high molecular weight hyaluronic acid on osteoarthritis of the knee. Int J Clin Pharmacol Ther Toxicol 1982;20:501-7.

16 Dixon AS, Jacoby RK, Berry H, Hamilton EB. Clinical trial of intra-articular injection of sodium hyaluronate in patients with osteoarthritis of the knee. Curr Med Res Opin 1988;11:205-13.

17 Grecomoro G, Martorana U, Di MC. Intra-articular treatment with sodium hyaluronate in gonarthrosis: a controlled clinical trial versus placebo. Pharmatherapeutica 1987;5:137-41

18 Peyron JG. Intraarticular hyaluronan injections in the treatment of osteoarthritis: state-of-the-art review. J Rheumatol 1993;20 (suppl 39):10-15.

19 Engstrom-Laurent A, Hallgren R. Circulating hyaluronic acid levels vary with physical activity in healthy subjects and in rheumatoid arthritis patients. Relationship to synovitis mass and morning stiffness. Arthritis Rheum 1987;30: 1333-8.

20 Pitsillides AA, Worrall JG, Wilkinson LS, Bayliss MT, Edwards JC. Hyaluronan concentration in non-inflamed and rheumatoid synovium. Br J Rheumatol 1994;33:5-10.

21 Kawaguchi Y, Kitani A, Hara M, Harigai M, Hirose T, Suzuki K, et al. Cytokine regulation of prolyl 4-hydroxylase production in skin fibroblast cultures from patients with systemic sclerosis: conribution to collagen synthesis and fibrosis. J Rheumatol 1992;19:1195-201.

22 Haubeck HD, Kock R, Fischer DC, van Leur E, Hoffmeister $\mathrm{K}$, Greiling $\mathrm{H}$. Transforming growth factor beta 1 , a major stimulator of hyaluronan synthesis in human synovial lining cells. Arthritis Rheum 1995;38:669-77.

23 Kawakami A, Eguchi K, Matsuoka N, Tsuboi M, Kawabe Y, Aoyagi $\mathrm{T}$, et al. Inhibition of fas antigen-mediated apoptosis of rheumatoid synovial cells in vitro by transforming growth factor $\beta 1$. Arthritis Rheum 1996;39:1267-76.

24 Suzuki M, Asplund T, Yamashita H, Heldin CH, Heldin P. Stimulation of hyaluronan biosynthesis by platelet-derived growth factor-BB and transforming growth factor-beta 1 involves activation of protein kinase C. Biochem J 1995;307:817-21.

25 Massague J. The transforming growth factor-beta family. Annu Rev Cell Biol 1990;6:597-641.

26 Sporn MB, Roberts AB. Transforming growth factor-beta: recent progress and new challenges. J Cell Biol 1992;119: $1017-21$.

27 Kuruvilla AP, Shah R, Hochwald GM, Liggitt HD, Palladino MA, Thorbecke GJ. Protective effect of transforming growth factor $\beta 1$ on experimental autoimmune disease in mice. Proc Natl Acad Sci USA 1991;88:291821

28 Allen JB, Manthey CL, Hand AR, Ohura K, Ellingsworth L, Wahl SM. Rapid onset synovial inflammation and hyperplasia induced by transforming growth factor beta. J Exp Med 1990;171:231-47.

29 Elford PR, Graeber M, Ohtsu H, Aeberhard M, Legendre $\mathrm{B}, \mathrm{Wishart}$ WL, et al. Induction of swelling, synovial hyperplasia and cartilage proteoglycan loss upon intra-articular injection of transforming growth factor beta- 2 in the rabbit. Cytokine 1992;4:232-8.

30 Brandes ME, Allen JB, Ogawa Y, Wahl SM. Transforming growth factor beta 1 suppresses acute and chronic arthritis in experimental animals. J Clin Invest 1991;87:1108-13.

31 Thorbecke GJ, Shah R, Leu CH, Kuruvilla AP, Hardison $\mathrm{AM}$, Palladino MA. Involvement of endogenous tumor necrosis factor alpha and transforming growth factor beta during induction of collagen type II arthritis in mice. Proc Natl Acad Sci USA 1992;89:7375-9.

32 Gotoh S, Onaya J, Abe M, Miyazaki K, Hamai A, Horie K, et al. Effects of the molecular weight of hyaluronic acid and its action mechanisms on experimental joint pain in rats. Ann Rheum Dis 1993;52:817-22.

33 Aruffo A, Stamenkovic I, Melnick M, Underhill CB, Seed B. CD44 is the principal cell surface receptor for hyaluronate. Cell 1990;61:1303-13. 